\title{
Environment-Friendly Energy Research in Norway
}

\begin{abstract}
The Research Council of Norway established the Centres for Environment-Friendly Energy Research in 2009. These are long-term national centres that are meant to integrate academics with industries, private companies, regulating bodies, governmental organisations, and research institutes, to trigger a clean-energy transition and pursue environmental innovations. Increasingly, addressing energy issues through the integration of technological and Social Sciences and Humanities disciplines has become expected in these Centres. This chapter draws from interviews with the project participants and fieldwork to demonstrate how different academics and professionals experienced these interdisciplinary collaborations, including what consequences and dynamics such collaborations generated. We round up by interpreting the findings along with the traits of interdisciplinarity that have been emerging in this book.
\end{abstract}

Keywords The Research Council of Norway • Research funding • Publications • Social Sciences and Humanities • Environmental innovation 


\subsection{INTRODUCTION}

Low-carbon transitions of energy systems are multi-dimensional and complex sociotechnical processes. As has been now shown in this book, it has become increasingly expected that interdisciplinary research-that crosses academic disciplines, as well as quite often sectors and policy areas toowill develop new knowledge and help address this situation. Over the past years, academic disciplines from the Social Sciences and Humanities (SSH) have therefore been especially expected to contribute new knowledge to energy research, policy, and innovation and hence further energy transitions in societies.

In line with this trend, the Research Council of Norway established the Centres for Environment-friendly Energy Research (Forskningssentre for miljøvennlig energi, from here on, FMEs, as they are commonly abbreviated) in 2009. These are long-term national centres that are meant to integrate academics with industries, private companies, regulating bodies, governmental organisations, and research institutes to trigger a cleanenergy transition and pursue environmental innovations. Increasingly, integrating technological and SSH disciplines to address energy issues has become normatively required in these Centres. The chapter draws from interviews with the project participants and fieldwork to demonstrate how different academics and professionals worked in these interdisciplinary collaborations and what consequences and dynamics their knowledge production has had. In Chap. 5, we move to discuss on a more general level how a consultancy evaluated these large-scale interdisciplinary Centres.

This chapter presents findings from fieldwork concerning the FMEs, conducted in 2019. Science and Technology Studies (STS) has led us to consider the FMEs not just as a new policy instrument, but also as an opportunity for conducting field research on how its research was actually carried out in a collaboration (with the SSH, as well as other disciplines). The corpus includes qualitative interviews with professionals aligned with and around the FMEs. The scope of the data collection spans various actors including research group leaders, coordinators, and researchers. Ten interviews have been conducted with representatives of seven different FMEs. Although not a large number and not representative of all FMEs, these data are complemented by other means and offer a unique view into the knowledge production and its dynamics happening within the FMEs. 
In contrast to the classic objects of Science Studies (cf. Silvast and Virtanen 2019), the FMEs are primarily not set up as laboratories, research groups, or other single sites of expert knowledge. Some of them have an actual office where they are located and that could be visited by an ethnographer, but some of them do not and they exist mainly as virtualnetworked organisations. The FMEs also run seminars, workshops, training for $\mathrm{PhD}$ researchers, and other related events, but these do not happen all the time and will involve various subsets of the FME members. As large centres, their trait is being geographically distributed across Norway and they were initially conceived to set up 'national teams'. They involve very different kinds of actors, from researchers in various universities and research institutes to project partners in the industry, business, and public enterprises that also provide about half of the FME funding (Impello 2018). All of this means difficulties for conducting a 'field study' of the FMEs because of the difficulty of defining 'what a field is' in this case.

To address this methodological requirement of overcoming the singlecase research designs, this research uses several strategies. The first is studying many of the FMEs in the same (cross-FME) projects, rather than just a single case study in one of them. Secondly, we use other techniques from interviewing to place the FMEs in the broader context of research policy and the evolution of academic research in Norway. To accomplish this, the research presented in this chapter gathered an overview of what has been written about the FMEs often by their participants themselves by developing an SSH perspective. A literature review of the FMEs was completed and is depicted in Table 3.1. A selected subset of all the discovered

Table 3.1 Reviewing the Centres for Environment-Friendly Energy Research in scientific databases

\begin{tabular}{lllll}
\hline Search term & Oria & $\begin{array}{l}\text { Web of } \\
\text { Science }\end{array}$ & Scopus & $\begin{array}{l}\text { Google } \\
\text { Scholar }\end{array}$ \\
\hline $\begin{array}{l}\text { "Centres for Environment-Friendly Energy } \\
\begin{array}{l}\text { Research" } \\
\text { "Forskningssentre for miljøvennlig energi" } \\
\text { "Forskningssentrene for miljøvennlig energi" }\end{array}\end{array} \quad 9 \quad 1 \quad 3$ & 4 & 382 \\
\hline
\end{tabular}

${ }^{a}$ Oria is a unified library database in Norway, including books, articles, magazines, music, films, and electronic resources. It is maintained by BIBSYS, an agency established by the Ministry of Education and Research in Norway. It is a collaboration among all the Norwegian universities, university colleges, research institutions, and the National Library of Norway. The Norwegian University of Science and Technology (NTNU) has the formal organisation of BIBSYS 
studies was gathered, focusing on those works that apply SSH (whereby the Social Sciences includes Economics) perspectives or methods to examine the FMEs or that embed energy issues in economy or society whilst discussing the FMEs. The result was 75 works developed from a sociotechnical perspective, including both peer-reviewed journal articles and grey papers. In what follows, both the interviews and desk-based overviews of this literature are deployed to address the main research goals.

This chapter is structured as follows: we begin with background context on the FMEs themselves (Sect. 3.2), after which we summarise the outcomes of our analysis on FME publication outputs (Sect. 3.3.1). Following this context, we first examine how interdisciplinary knowledge production is carried out in FMEs (Sect. 3.3.2); qualitatively map the academic disciplines in the FMEs (Sect. 3.3.3); and study the interpretations of innovation that the FMEs are drawing upon (Sect. 3.3.4). We finish this chapter with some conclusions on a programme at the Norwegian University of Science and Technology (NTNU) that has tried to straddle all the FMEs and combine them under one 'umbrella' initiative on energy transitions, asking what such merger means for interdisciplinarity.

\subsection{What Is Environment-Friendly Energy RESEARCH AND INNOVATION IN NORWAY?}

The political consensus on addressing climate issues and the role of academic research in generating knowledge to that aim are long-standing developments in Norway. The Norwegian Declaration of Soria Maria in 2005 emphasised environment and climate and stressed global challenges including energy issues. The 2008 climate contract by all political parties increased research resources on clean energy studies (Pelkonen et al. 2010). Energi2 1, a national strategy for research, development, and commercialisation of climate-friendly energy technologies, was established in the same year. Evaluations have argued that SSH research on energy and climate issues was prioritised in these programmes (Klitkou et al. 2010). They also claimed that had been a visible growth in research collaborations, networks, and scientific articles and citations in Norwegian energy research that draws on SSH perspectives (Ramberg et al. 2016).

In practice, however, the contributions of and tasks attributed to $\mathrm{SSH}$ in environment-friendly energy research varied across research programmes and changed substantively over time. In 2009, the Research 
Council of Norway established a historical response to the climate agreement by granting eight Norwegian Centres for Environment-Friendly Energy Research (Forskningssentre for miljøvennlig energi, FME). Characterised initially as a technology-push initiative (Jakobsen et al. 2019), the FMEs are long-term centres whose remits include increasing innovation; contributing to national and international emissions reduction, energy efficiency, and renewable energy; promoting the development of research environments; and knowledge-based contributions to energy debates (Norges forskningsråd 2018a). The FMEs work through university-industry collaboration (Nilsen and Lauvås 2018) and focus on what researchers term as environmental innovations. These are products, production processes, services, and management and business models that are novel in an organisation and reduce negative impacts to the environment (Jakobsen et al. 2019).

These initial FMEs focused on a number of technological areas: including energy use in buildings and regions; solar energy and materials for solar cells; bioenergy including biofuels; hydropower; Carbon Capture and Storage; and energy systems. Between now and then, a large share of the FME funding has been distributed to research on buildings, solar energy, and bioenergy (Impello 2018).

While all the initial Centres were technological, three further were granted in 2011 specifically on SSH aspects of energy and climate (CICEP, Strategic Challenges in International Climate and Energy Policy; CREE, Oslo Centre for Research on Environmentally Friendly Energy; and CenSES, Centre for Sustainable Energy Studies). These SSH-based FMEs aimed to improve the knowledge base for energy policy and public and private decision making (Government.no 2013). The year 2016 saw the granting of further, both technological and SSH-focused FMEs which included new themes on energy efficiency in industry and zero emission transport. In 2019, the Research Council of Norway granted two more SSH-focused FMEs on energy transition strategies and socially inclusive decarbonisation, respectively. The newest FME to date is the Norwegian Research Centre on Wind Energy. An overview of the areas of the FMEs to date is in Table 3.2.

At this point, the integration of SSH disciplines also became mandatory for the technological Centres. As the Research Council of Norway (Norges forskningsråd 2018b, p. 2) summarised, the FME scheme is meant to integrate key disciplines and research environments related to energy issues: it "engages social scientific, humanities, and science and technology 
Table 3.2 Overview of the Centres for Environment-Friendly Energy Research, as of 15 June 2021. Data sourced from project database of the Research Council of Norway

\begin{tabular}{|c|c|c|}
\hline Name & $\begin{array}{l}\text { Budget } \\
(M)\end{array}$ & $\begin{array}{l}\text { Project } \\
\text { period }\end{array}$ \\
\hline \multicolumn{3}{|l|}{ Technology-oriented FME centres } \\
\hline Norwegian Research Centre on Wind Energy & NOK 120 & $2021-2029$ \\
\hline Research Centre for Sustainable Solar Cell Technology & NOK & $2017-2024$ \\
\hline Norwegian Centre for Sustainable Bio-Based Fuels and Energy & $\begin{array}{l}\text { NOK } \\
124.8\end{array}$ & $2017-2024$ \\
\hline Mobility Zero Emission Energy Systems & NOK 120 & $2017-2024$ \\
\hline $\begin{array}{l}\text { Centre for an Energy Efficient and Competitive Industry for } \\
\text { the Future }\end{array}$ & $\begin{array}{l}\text { NOK } \\
200.2\end{array}$ & 2016-2024 \\
\hline $\begin{array}{l}\text { The Research Centre on Zero Emission Neighbourhoods in } \\
\text { Smart Cities }\end{array}$ & NOK 176 & 2016-2024 \\
\hline Norwegian CCS Research Centre & $\begin{array}{l}\text { NOK } \\
184.4\end{array}$ & 2016-2024 \\
\hline Norwegian Research Centre for Hydropower Technology & NOK 192 & 2016-2024 \\
\hline Centre for Intelligent Electricity Distribution & NOK 160 & 2016-2024 \\
\hline Subsurface CO2 Strategy & NOK 80 & 2010-2018 \\
\hline FME Solar United & NOK 160 & 2009-2017 \\
\hline Norwegian Centre for Offshore Wind Energy & NOK 120 & 2009-2017 \\
\hline FME CenBIO (Bioenergy Innovation Centre) & NOK 120 & 2009-2017 \\
\hline Centre for Environmental Design of Renewable Energy & NOK 80 & 2009-2017 \\
\hline The Research Centre on Zero Emission Buildings & NOK 120 & 2009-2017 \\
\hline BIGCCS Centre (International CCS Research Centre) & NOK 160 & 2009-2017 \\
\hline $\begin{array}{l}\text { FME NOWITECH (Research Centre for Offshore Wind } \\
\text { Technology) }\end{array}$ & NOK 160 & 2009-2018 \\
\hline Social Sciences-related FME centres & & \\
\hline $\begin{array}{l}\text { FME INCLUDE (INCLUsive Decarbonisation and Energy } \\
\text { Transition) }\end{array}$ & NOK 95 & 2019-2027 \\
\hline Norwegian Centre for Energy Transition Strategies & NOK 105 & 2019-2027 \\
\hline $\begin{array}{l}\text { CICEP (Strategic Challenges in International Climate and } \\
\text { Energy Policy) }\end{array}$ & NOK 64 & $2011-2020$ \\
\hline $\begin{array}{l}\text { CREE (Oslo Centre for Research on Environmentally Friendly } \\
\text { Energy) }\end{array}$ & NOK 64 & $2011-2020$ \\
\hline CenSES (Centre for Sustainable Energy Studies) & NOK 80 & $2011-2019$ \\
\hline
\end{tabular}

See: https://prosjektbanken.forskningsradet.no/explore/projects?Kilde=FORISS\&distribution=Ar\&cha $\mathrm{rt}=$ bar\&calcType $=$ funding $\&$ Sprak $=$ no\&sortBy $=$ date \&sort Order $=$ desc\&result Count $=30 \&$ offset $=0 \&$ Prog Akt.3=FMETEKN-FME+-+teknologi and https://prosjektbanken.forskningsradet.no/explore/projects? Kilde $=$ FORISS $\&$ distribution $=$ Ar\&chart $=$ bar\&calcType $=$ funding $\&$ Sprak $=$ no\&sortBy $=$ date $\&$ sortOrder $=\mathrm{d}$ esc\&resultCount=30\&offset=0\&ProgAkt.3=FMESAMFUNN-FME+-+samfunn 
research environments, and in several cases, takes an interdisciplinary and multidisciplinary approach".

Explicitly, the FMEs are expected to engage the SSH in the study of energy policy, behavioural change, dissemination of new technologies, and business studies (Norges forskningsråd 2018b, p. 8). These are typical, anticipated contributions from the SSH disciplines in energy research (Mallaband et al. 2017; Silvast et al. 2013). They appear at a partial stage of innovation: they contribute new knowledge and address innovations at their very late stage, of diffusion. Typically, this means that SSH are requested to study the behaviour of eventual technology 'end-users' (Ingeborgrud et al. 2020; Silvast et al. 2018) or public acceptance of new technologies (Robison and Foulds 2021; Ryghaug et al. 2018). This is where strong SSH contributions are envisaged, essentially to overcome resistance: it has been argued that the scientist participants in one of these FME centres anticipate a public that lacks information and will be resistant to new energy technologies (Heidenreich 2015).

However, emerging international research has spoken to considerably wider participation of different academic disciplines and stakeholders in the earliest stages of innovation and technology development. This is meant to contribute to the anticipation, reflection, engagement, and activity of all relevant societal actors in technology design, that is to say, Responsible Research and Innovation (RRI) (Rommetveit et al. 2017; von Schomberg 2011). Especially sustainable development has been associated with a wholly new concept of Transformative Innovation Policy (TIP) (Schot et al. 2018; Schot and Steinmueller 2018). This concept designates innovation that goes beyond technology development and design and embraces inclusivity, organisational change, and experimentation. The transformative focus implies acknowledging "civil society and citizens as not only consumers and adopters of innovation but as promotors and sources for innovations which address social and environmental needs" (Schot et al. 2018, p. 8).

The FMEs, with their primary focus on environmental innovation, line up with these considerations directly. Several detailed studies on the working practices of FMEs have been conducted by academics, examining how their members describe trade-offs between innovations and academic outputs (Nilsen and Lauvås 2018) and respond to external energy policy objectives coherently (Åm 2015; Jakobsen et al. 2019). But also, in contrast to several countries with a long-term innovation model—such as Finland, Sweden, and the Netherlands - the first Norwegian official joint statement 
on innovations was published relatively recently in 2008 (Norwegian Ministry of Trade and Industry 2008). More recently, the discussion has expanded in the policy, professional, and academic sense, and the Research Council of Norway has backed both the RRI and the TIP concept (TIP Consortium 2017). As these considerations demonstrate, the role of SSH in the FMEs and environmental innovation merits further interrogation and has not been fully acknowledged by existing research and evaluations.

\subsection{The Role of Social Sciences and Humanities in Norwegian Environment-Friendly Energy RESEARCH AND INNOVATION}

\subsubsection{Centres for Environment-Friendly Energy Research in the Literature}

The collected publications on the FMEs, deploying SSH perspectives (Fig. 3.1), display a clear trend. Almost directly after their foundation in 2009 , there is a rising interest in studies of FMEs. This is understandable:

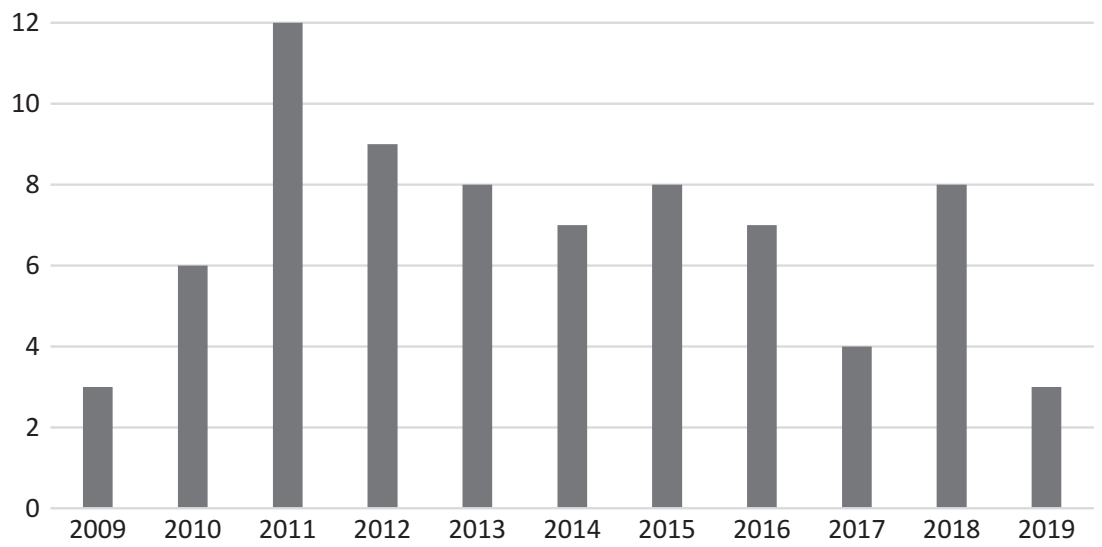

Fig. 3.1 The number of Social Sciences and Humanities publications published by all Centres for Environment-Friendly Energy Research, per year (2009-2019). Sources: Oria, Web of Science, Scopus, Google Scholar 
an increasing number of works will find it interesting to study that there is a new major funding instrument in Norway. After 2011, the number drops off and there is no visible trend after that, which suggests that while the number of FMEs had increased, there was no consistent accumulation of discussions on them. The publication types (Fig. 3.2) show that the majority of this type of publishing has happened in various grey literatures, especially reports and non-reviewed conference papers. This can be readily explained by the composition of these Centres: some of the FMEs are led by and have large budgets in public research institutes that do not always have a strong academic publishing tradition. Journal articles, however, represent the second largest group. The articles are not published in any particular main journal, with the exception of Energy Procedia that publishes conference proceedings and contains the largest number of publications. The outlets of the rest range from the Norwegian Forskningspolitikk (research policy) to Environmental Innovation and Societal Transitions, Economic Geography, Energy Policy, and Science and Public Policy, and various others with only a few publications per each journal.

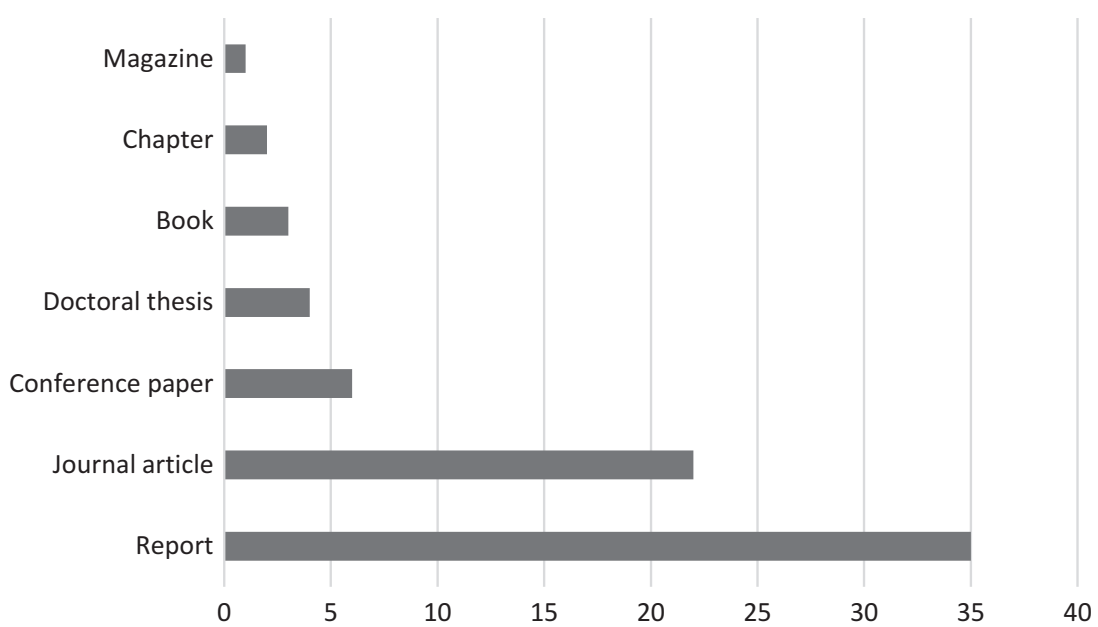

Fig. 3.2 The number of Social Sciences and Humanities publications published by all Centres for Environment-Friendly Energy Research, per publication type (2009-2019). Sources: Oria, Web of Science, Scopus, Google Scholar 
The author-provided keywords provide an important first viewpoint into what the scholars themselves were writing about, when reflecting on the FMEs from a sociotechnical perspective. The complete list of words is in Table 3.3. One can immediately see the lack of important keywords: there is no interdisciplinarity, multidisciplinarity, or transdisciplinarity. Even more strikingly, there are no keywords on any kind of innovation. There are, however, a number of visible interests in policy and politics including both energy and climate. The links between the industry and

Table 3.3 Authors' keywords when studying the Centres for EnvironmentFriendly Energy Research

\section{Keyword}

- Absorptive capacity

- Actor-based approach

- Agenda setting

- Arena of development

- Branching

- CCS

- Climate policy

- Emissions

- Energy

- Energy policy

- Environment

- Environmental Sciences and Ecology

- Renewables

- International R\&D consortium collaboration

- Climate gas

- Knowledge integration

- Learning curve

- Norway

- Offshore wind

- Path creation

- Path dependence

- Path interdependencies

- Policy

- Politics

- R\&D support

- Solar

- Sustainability transitions

- Technological development

- Translation 
the academia — such as research and development (R\&D) issues-also clearly received interest. Several articles are written centred on technologies as such, corresponding with how the FMEs were setup: including offshore wind and solar energy. That said, there are also some more systems-oriented perspectives, which mainly seem to stem from various kinds of transitions studies. These include focuses on path dependencies and path creation, path interdependencies, and sustainability transitions as such.

The interpretation of these key focuses follows from the way in which the SSH were meant to work in the FMEs, by design. As mentioned above, the funder's interest in "social science FMEs" corresponded with a focus on energy policy, decision making (Government.no 2013), behavioural change, dissemination of new technologies, and business studies (Norges forskningsråd 2018b, p. 8). With the exception of behavioural studies, nearly all of these themes are present in the keywords. When publishing about the FMEs, SSH perspectives do not seem to have started from transgressing disciplinary boundaries, but closer to their set task, which was providing the FMEs with a social and political framing and increasing understanding of how the FMEs could collaborate between the academia and the industries. It is also revealing that these assumed SSH perspectives did not address innovation as their topic. This may be because innovation did not feature as a central concept or frame in the research practice and the research outputs; or because when innovations were defined, they were framed simply as commercialised inventions (Schot and Steinmueller 2018) to whose study many disciplines from the SSH did not have a predefined role. This finding will be deepened by the interviews with the FME project experts.

\subsubsection{Interdisciplinary Knowledge Production}

The following draws from the completed interviews for this research, gathered from different seniorities in various FMEs in 2019. These informants that had experienced working in the FMEs recognised that interdisciplinarity had been a strong requirement when the FMEs were setup, especially since 2011 after the initial rounds that had centred on technological disciplines. As many of them continued, a difference exists, however, between designing interdisciplinary collaboration as part of an application and making this collaboration happen in everyday research and all the time. These are well-recognised issues in the interdisciplinarity 
studies (Winskel 2018; Winskel et al. 2015) and were suggested in the Norwegian case. Firstly, integrating different knowledge from various disciplines takes time and effort that were not always sufficiently anticipated by the participants or in research designs. Had this social learning been allocated more resources, it might have happened more frequently or rapidly according to the research participants. In the early centres, it happened often but in certain situations, as when one of the early Centre project members used social practice theory and the Multi-Level Perspective to translate some SSH insights to building research practice:

I think I used [sociologist and practice theorist Elizabeth] Shove's work a lot, Comfort, Cleanliness, and Convenience. That was very easy to communicate [for building managers and engineers]. At some, we also used a lot of the Multi-Level Perspective (MLP). Despite all its criticisms, it is really easy to communicate, it opens up some ice. [At] One of these conferences, I used the MLP to contrast the diffusion curve with the MLP. I think it was useful for many people. (Man, 50-59 years, Professor)

This quote points to the role of reducing complexity and translations, even when the concepts to do this, such as the MLP, can be criticised from certain perspectives. This should not overlook, however that secondly, knowledge from various academic disciplines is not always only difficult, but can in some cases be nearly impossible to integrate, even as a purely practical matter. A typical example, which was pertinent to many of the Norwegian Centres, was the difference between the modelling-based knowledge used for example in optimising power systems or analysing sensor data from buildings, as compared to the more qualitative evidence expected from the SSH. When these kinds of knowledge practices meet, they reveal different epistemic values, assumptions, and units of analysis that cannot be reconciled by simply, for example, feeding social scientific data into energy systems models. Thirdly, the informants recognised that academia's reward structures are not ideally suited for interdisciplinary knowledge production-as, for example, many key scientific journals in research fields remain monodisciplinary. It may be telling of this that many of the FMEs, when they published on SSH issues, did it on channels that were not academic journals (see the previous section).

While working across disciplines was often seen as in need of continuous maintenance, this did not mean that SSH had no role in the research practices. In many cases, the SSH were given a predefined task in the 
Centres whether by work package structure or set roles on what these disciplines were expected to do. In the example of research on energy efficiency in buildings and sustainable energy studies, the typically assigned role was studying the 'users', whether in user experiments or in behaviour of the resident 'users' or households more generally. This assumption also brought about a specific temporal location in the research process- the SSH were often introduced to the studies 'after the fact' when the technologies had already been designed and needed to be diffused to their expected 'users'.

SSH perspectives could also find roles in some of the other key concerns of the FMEs. One of these was innovation, as two scholars who had both worked in FMEs and researched them explained. There was a different agreement on what it would mean to be an innovation scholar that shaped how the end-user partners and the SSH researchers would expect to work in the projects:

A: Some [user partners] think that $O K$, you are an innovation researcher, so you are the ones that are going to make the innovation happen, that is the most extreme view that you meet. (Man, 30-39 years, Researcher)

$B$ : We were responsible for our innovation, that we manage and create innovation, commercialisation, technology, and so on. We really have to tell them real hard that we are doing research and that research has implications for how they manage innovation. (Woman, 40-49 years, Research Director)

A: that we can contribute to the process, but they cannot "outsource" it to the social sciences, they have to do the technical development. We have done work for one of the FMEs and given input to the centre management how it is going, and what they can do differently. (Man, 30-39 years, Researcher)

This quotation shows both the differing expectations-where the user partners assumed that SSH scholars would make innovations happen, the SSH scholars thought they would do research that would frame innovations for the partners - and the clear need for active maintenance work in interdisciplinarity. The SSH scholars needed to do continuous maintenance of their relationship with others and express what their contribution to knowledge is. In the term 'outsourcing', there is an implicit assumption that was the relationship not actively maintained, it would default back to kind of a provider of a service, such as innovation management instead of scholarship of innovation in its own right. 
There were several other similar examples of roles and expectations. Another potential role again related to the interest of several industrial FME user partners, namely communication. Communication meant making the results of the FMEs more visible outside of the circle of their developers. In making this communication happen, it seems to have been recognised that 'social' framing, as well as 'technical' framing, of the new technologies was necessary. But it would be premature to associate this communicative practice with inclusive attention to innovations. This is because it operated mainly to one direction. When it involved other actors than developers and designers, it did so simply aim at informing these of new scientific discoveries.

\subsubsection{Academic Disciplines Involved from Social Sciences and Humanities}

The FMEs are technology-oriented, but in planning them, crossing disciplines has been increasingly required and the SSH have been preferred to be involved. Disciplinary diversity was hence prized by the FMEs and their participants. That said, when attempting to map which disciplines exactly were involved in these collaborations, it is important to question the relevance of disciplinary labels especially as part of everyday working in the Centres. To some extent, the interviewees drew on disciplinary 'gaps' by using the labels when we mentioned them. Generally, there simply was not that much SSH involvement, even in terms of number of staff, in the more technological Centres. This also meant lacking some disciplines for the problems that these Centres were addressing. For example, Environmental Psychology could have brought insights on buildings and energy efficiency, and planning-oriented disciplines-such as Geography or Sociology - might have been of considerable help in researching energy in urban areas. One participant from an SSH-focused FME also made distinctions between which disciplines from the SSH integrated more than the others. She had found out that disciplines studying 'technology users' had clear contributions, but that the Political Sciences had found their roles more contested, on the count of introducing findings on the political implications of energy technologies which some participants might have not preferred as objects of analysis.

Yet, it was also clear that these disciplinary labels were somewhat constructed in the interview situation itself. It did not seem like everyday research in the FMEs had relied on scholars always identifying with their 
own academic discipline, for example, based on where they received their doctoral degree. The case of 'user studies' is again a good illustration, as this problem could be engaged by a number of disciplines and interdisciplinary fields, ranging from STS to Sociology, Anthropology, HumanCentred Design, Cultural Studies, and beyond that. Scholars who pursue understanding the 'user' may do so in terms of that practical problem rather than as anthropologists, sociologists, and so forth.

Another popular example, related to installing large-scale energy technologies - such as Norwegian hydropower-in localities, is when the role of SSH becomes translated into 'social acceptance' research. An interview quote below makes no practical difference between the Social Sciences and social acceptance research, but, for this purpose, equates them with one another:

When it comes to the social sciences, the companies are also in the process of maturing. Because there's been a lot of focus on the biological part, hydropower companies have been addressing fish populations... What they see now is to include and look at the social acceptance, when it comes to upgrades and expansion, they have to have a kind of addressing and some kind of insights into social acceptance issues. A very good acceptance and acknowledging the social sciences in order to have a good collaboration with local interests. (Woman, 40-49 years, Executive Director)

She worked for one of the technical FME centres, and one could assume that with the link from energy installations to social acceptance, local interests, and the Social Sciences to study and translate between interests and acceptance them, there would be a very large role for crucial SSH insights both conceptually and in the applied sense. Indeed, this is a large and evolving research area, where new openings exist spanning from Political Science to Anthropology, Sociology, Geography, Ecology, and beyond (Wolsink 2018). To do research on users, social acceptance, or other themes framed by technologists does not automatically cause restricted research agendas.

But this was still not always the case, according to the participants. An important and critical example of disciplinary positions and roles needs to be explained here-this one used by the interviewed SSH scholars themselves. Some of the project participants felt that their SSH perspectives had been minor in the research. This could have happened in a number of different ways. One of them directly followed from the social acceptance 
focus and was based on the deficit model of the public (Ryghaug et al. 2018) - namely, in another Centre than the one above, it was first assumed that SSH study the 'end-users' and acceptance issues, but then questioned whether it made sense to interview these technology users when they might have lacked relevant information on energy technologies and hence been unable to generate new scientific knowledge on these technologies. Another assumption at play was associating SSH with mere theory but not connected to actual development and design of technology. These assumptions on ineffective contributions by these disciplines were sometimes reinforced by project design, for example, by letting the SSH participants sit in management boards but keeping them at a distance as one interview participant (Man, 40-49 years, researcher) put it, from everyday research practice.

\title{
3.3.4 The Interpretations of Innovation
}

Considering that the FMEs were explicitly set up to increase innovations, it is important to highlight how much the concept of innovation had fluctuated during the life course of these large Centres. Some of the informants suggested that innovation was a new concept to the FMEs themselves. In fact, we should stress the unusual place of these centres in the Norwegian funding system, since innovation funding and research funding had historically separate funding streams, expectations, and even institutions that deal with each of them (with, for instance, SINTEF focusing on innovation and NTNU focusing on research, though the two collaborate intensely). One of the participants in the early centres noted:

\begin{abstract}
In 2009, the FMEs were new, and research institutions had to find out how to organise them. And we discussed this after 4 years in one of the FMEs that this is a bybrid: between centre of excellence research and a centre for innovation, which are two funding instruments that had existed before. It was supposed to do both at the same time, producing high-quality research and also producing practical solutions to climate change. (Man, 50-59 years, Professor)
\end{abstract}

The concept of innovation had strengthened after the evaluations of the FMEs, when some industrial partners wanted to seek more problemoriented solutions from the Centres. Accordingly, the industrial partners expected short-term and concrete results, which some interviewees termed directly as innovations. 
Around this same time, the funders seem to have systematised their attention on innovation. But this initial work linked with pursuing the Centres to use the concept of innovation at all, rather than more reflective or theoretical discussions on what the concept could mean. Many stressed that innovations were mainly seen as commercialised inventions that should ideally be counted and otherwise measured. The key tool of this calculation of produced activity were Technology Readiness Levels: an estimate on the maturity of technologies, especially in this case, to enter the markets as new products. According to many of the accounts, the recent discussion in FMEs on innovations centred on how the technologies developed could climb the Technology Readiness Levels towards actual demonstrations and products. As this was still a relatively new discussion, it had to be pursued by special arrangements at the time of the study, such as involving professional 'innovation managers' in the Centres and setting up innovation boards where they would meet the other project members and leaders.

Innovation managers and other related professionals were not clearly experts of any particular academic discipline, although their work leaned on commercial principles. That said, one project participant accounted an earlier experience, where the SSH were designed into the Centre to act as innovation experts in the management groups. These arrangements point out to the flexibility of the idea of innovation and how it opened up to participation of, at least, various kinds of experts in the academia and those mediating in between universities and the industries.

\subsection{Conclusions}

The chapter addressed how the FMEs have worked as a way of conceptualising transformative change anew in interdisciplinary energy research and what relationships to policy they were meant to develop. The findings show how the energy transformation in these cases was opened up to the broad involvement of different academic disciplines, including SSH, but also limited to this involvement of each of these disciplines to specific set roles. The result was not radical interdisciplinarity per se, but instead academic disciplines pursuing research on a predefined task, whether it be 'end-users' or energy policy in the case of SSH. In fact, the high-level labels set around 'social scientific' and 'technological' FMEs by the funding body suggest two dynamics, already recognised in the previous chapter. First, there is an indication of SSH being appropriated (Forsythe 
1999) by other disciplines by configuring them certain roles in the project. Second, the fact that some FMEs are still called Social Science suggests that the importance of disciplines has not diminished in these interdisciplinary collaborations. On the contrary, the SSH are brought forward as a seemingly unified one discipline that can address relevant energy issues. There are grounds to draw on such labels - a theme we return in Chap. 5 -but it needs to be done strategically, while respecting the diversity of SSH disciplines and highlighting the often-backgrounded techniques and tools that being labelled as a certain kind of 'social scientist' (or SSH scholar) can offer to other academics.

The research also discussed how the concepts of environmental innovation and university-industry collaboration were framed in the context of the FMEs and how the FMEs themselves have perceived these new approaches. These new approaches involved industrial partners, public institutions, and various others, but it was also visible who was not involved: there was little evidence of civil society actors, NGOs, or social movements being engaged in the FMEs' work and innovations that were studied. The concepts of environmental innovation and transdisciplinary collaboration have evidence of interpretative flexibility. We can critique these different interpretations for what they miss, but on the other way, they also likely have produced coherence to the projects studied. In this, they can function as 'boundary objects' (Star and Griesemer 1989) that integrate different social worlds of the project and give them goals to aspire to.

The role of research funding becomes perhaps most pronounced in this chapter, as it has set about explicitly studying large national centres that were established and financed by the national funding organisation. It is clear that the funder has been actively discussing this interest and developing new viewpoints on what the Centres were achieving (Impello 2018). We revisit this theme in depth in Chap. 5, when drawing together our interest on the impacts of research funding on interdisciplinary working.

We now conclude this chapter by drawing these interests together in the context of the Norwegian University of Science and Technology's Energy Transition Initiative (NETI), a research programme established at the NTNU between the main energy industry players and researchers. NETI aimed at generating knowledge-based energy transitions and 
setting up research environments to pursue this knowledge; one of the potential functions to do this was for it to become the 'umbrella organisation' of the FMEs in Norway. As it were, NETI wanted to stand as a hub to all the FMEs and their research problems and areas. Aside from the strategic aims of the initiative, it is in the interest of this book because it demonstrates whether, and if so how, the current energy transition can be merged under one overarching approach especially as different academic disciplines are pursuing knowledge on it. The NETI offered to do this by not offering one single strategical pathway, but multiple strategies to transition in future energy systems. Its main themes, sourced from internal presentations (e.g. see Silvast 2019), were as follows: energy policy and scenarios; innovation and entrepreneurship; human behaviour/consumer research; energy storage, distribution, and technology development; energy markets and business models; and sustainability/climate research.

These themes are revealing of the diversity of issues and problems that an energy transition would require, according to the characterisation of NETI. The interviews in this chapter have similarly demonstrated the diversity of these topics, including the various epistemic cultures (Knorr Cetina 1999) at play, and how social learning was required in the FMEs to effectively cross between them.

It is also important to recognise that these themes around transition are organised around topics and problems, rather than broad academic disciplines. This problem-orientation poses a relevant approach to transition strategies but excludes the particular tools and methods that might be used to increase, for example, innovation, sustainability, and understanding in consumer research. In this way, the image masks epistemic differences between disciplinary tools-such as computer models used in scenarios and optimisation, as opposed to psychological, sociological, and anthropological knowledge on people and use of technologies. In order for a transformative innovation to be pursued, these epistemic values of different tools would require further attention. The orientation to problems as opposed to disciplines also poses a further problem: that many fields, such as STS, would not study these problems in isolation from one another, as they are quite clearly interrelated; for instance, energy policy is closely related to energy market design (Silvast 2017). In summary, the problem-oriented interdisciplinary research does not offer a single solution to the problems of disciplinary-based academic knowledge production. 


\section{REFERENCES}

Åm, H., 2015. The sun also rises in Norway: Solar scientists as transition actors. Environmental Innovation and Societal Transitions 16, 142-153. https://doi. org/10.1016/j.eist.2015.01.002

Forsythe, D.E., 1999. "It's just a matter of common sense": Ethnography as invisible work. Computer Supported Cooperative Work 8, 127-145. https://doi. org/10.1023/A:1008692231284

Government.no, 2013. Centres for environment-friendly energy research [WWW Document]. URL https://www.regjeringen.no/en/topics/energy/energyand-petroleum-research/centres-for-environment-friendly-energy-/ id633931/ (accessed 5.24.21).

Heidenreich, S., 2015. Sublime technology and object of fear: Offshore wind scientists assessing publics. Environment and Planning A 47, 1047-1062. https://doi.org/10.1177/0308518X15592311

Impello, 2018. Effekter av energiforskningen. [The effects of energy research.] Impello, Trondheim.

Ingeborgrud, L., Heidenreich, S., Ryghaug, M., Skjølsvold, T.M., Foulds, C., Robison, R., Buchmann, K., Mourik, R., 2020. Expanding the scope and implications of energy research: A guide to key themes and concepts from the Social Sciences and Humanities. Energy Research and Social Science 63, 101398. https://doi.org/10.1016/j.erss.2019.101398

Jakobsen, S., Lauvås, T.A., Steinmo, M., 2019. Collaborative dynamics in environmental R\&D alliances. Journal of Cleaner Production 212, 950-959. https:// doi.org/10.1016/j.jclepro.2018.11.285

Klitkou, A., Pedersen, T.E., Schwach, V., Scordato, L., 2010. Social science research on energy International and Norwegian studies. NIFU, Oslo.

Knorr Cetina, K., 1999. Epistemic cultures. Harvard University Press, Cambridge, MA. https://doi.org/10.2307/j.ctvxw3q7f

Mallaband, B., Wood, G., Buchanan, K., Staddon, S., Mogles, N.M., GabeThomas, E., 2017. The reality of cross-disciplinary energy research in the United Kingdom: A social science perspective. Energy Research and Social Science 25, 9-18. https://doi.org/10.1016/j.erss.2016.11.001

Nilsen, T., Lauvås, T.A., 2018. The role of proximity dimensions in facilitating university-industry collaboration in peripheral regions: Insights from a comparative case study in Northern Norway. Arctic Review on Law and Politics 9, 312-331. https://doi.org/10.23865/arctic.v9.1378

Norges forskningsråd, 2018a. Forskningssentrene for miljøvennlig energi (FME): Resultater og høydepunkter fra åtte FME-er. [Research Centers for Environmentally Friendly Energy (FME): Results and highlights from eight FMEs.] Forskningsråd, Oslo. 
Norges forskningsråd, 2018b. Energi (ENERGIX, FME, CLIMIT) årsrapport 2018. [Energy (ENERGIX, FME, CLIMIT) Annual Report 2018.] Forskningsråd, Oslo.

Norwegian Ministry of Trade and Industry, 2008. An innovative and sustainable Norway. Oslo.

Pelkonen, A., Teräväinen, T., Häyrinen-Alestalo, M., Waltari, S.-T., Tuominen, T., 2010. Tiedepolitiikan kansainvälisiä kehitystrendejä 2000-luvulla. [The International Trends of Science Policy in the 2000s.] Opetus-ja kulttuuriministeriön julkaisuja, Helsinki.

Ramberg, I., Børing, P., Klitkou, A., Solberg, E., 2016. Social science research on environmentally friendly energy in Norway. NIFU, Oslo.

Robison, R., Foulds, C., 2021. Social sciences and humanities for the European green deal: 10 recommendations from the EU Energy SSH Innovation Forum. Cambridge.

Rommetveit, K., Dunajcsik, M., Tanas, A., Silvast, A., Gunnarsdóttir, K., 2017. CANDID PRIMER: Including Social Sciences and Humanities scholarship in the making and use of smart ICT technologies. CANDID research project paper. University of Bergen, Bergen.

Ryghaug, M., Skjølsvold, T.M., Heidenreich, S., 2018. Creating energy citizenship through material participation. Social Studies of Science 48, 283-303. https://doi.org/10.1177/0306312718770286

Schomberg, R. von, 2011. Towards responsible research and innovation in the information and communication technologies and security technologies fields. Publications Office of the EU, Brussels.

Schot, J., Boni, A., Ramirez, M., Steward, F., 2018. Addressing the sustainable development goals through transformative innovation policy. TIP Consortium, Brighton.

Schot, J., Steinmueller, W.E., 2018. Three frames for innovation policy: R\&D, systems of innovation and transformative change. Research Policy 47, 1554-1567. https://doi.org/10.1016/j.respol.2018.08.011

Silvast, A., 2017. Energy, economics, and performativity: Reviewing theoretical advances in social studies of markets and energy. Energy Research and Social Science 34, 4-12. https://doi.org/10.1016/j.erss.2017.05.005

Silvast, A., 2019. The role of social sciences and humanities in Norwegian environment-friendly energy research and innovation. In: Towards a global research agenda for transformative innovation policy conference, Valencia, Spain, 4-5 November 2019. https://www.tipconsortium.net/poster/ the-role-of-social-sciences-and-humanities-in-norwegian-environmentfriendly-energy-research-and-innovation/

Silvast, A., Hänninen, H., Hyysalo, S., 2013. Energy in society: Energy systems and infrastructures in society. Science and Technology Studies 26, 1-13. https://doi.org/10.23987/sts.55285 
Silvast, A., Virtanen, M.J., 2019. An assemblage of framings and tamings: Multisited analysis of infrastructures as a methodology. Journal of Cultural Economy 12, 461-477. https://doi.org/10.1080/17530350.2019.1646156

Silvast, A., Williams, R., Hyysalo, S., Rommetveit, K., Raab, C., 2018. Who “uses” smart grids? The evolving nature of user representations in layered infrastructures. Sustainability 10, 3738. https://doi.org/10.3390/su10103738

Star, S.L., Griesemer, J.R., 1989. Institutional ecology, 'translations' and boundary objects: Amateurs and professionals in Berkeley's Museum of Vertebrate Zoology, 1907-1939. Social Studies of Science 19, 387-420. https://doi. org/10.1177/030631289019003001

TIP Consortium, 2017. Towards transformative innovation policy for Norway [WWW Document]. URL http://www.tipconsortium.net/transformativeinnovation-policy-for-norway/(accessed 5.24.21).

Winskel, M., 2018. The pursuit of interdisciplinary whole systems energy research: Insights from the UK Energy Research Centre. Energy Research and Social Science 37, 74-84. https://doi.org/10.1016/j.erss.2017.09.012

Winskel, M., Ketsopoulou, Irina, Churchhouse, T., 2015. UKERC interdisciplinary review. UKERC, London.

Wolsink, M., 2018. Social acceptance revisited: Gaps, questionable trends, and an auspicious perspective. Energy Research and Social Science 46, 287-295. https://doi.org/10.1016/j.erss.2018.07.034

Open Access This chapter is licensed under the terms of the Creative Commons Attribution 4.0 International License (http://creativecommons.org/licenses/ by $/ 4.0 /$ ), which permits use, sharing, adaptation, distribution and reproduction in any medium or format, as long as you give appropriate credit to the original author(s) and the source, provide a link to the Creative Commons licence and indicate if changes were made.

The images or other third party material in this chapter are included in the chapter's Creative Commons licence, unless indicated otherwise in a credit line to the material. If material is not included in the chapter's Creative Commons licence and your intended use is not permitted by statutory regulation or exceeds the permitted use, you will need to obtain permission directly from the copyright holder.

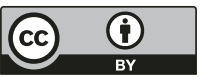

